\title{
Construction insolvency in Australia: reining in the beast
}

\author{
Jeremy Coggins, Bianca Teng and Raufdeen Rameezdeen \\ School of Natural and Built Environments, University of South Australia, Australia
}

\begin{abstract}
Insolvency has become endemic in the Australian construction industry. The scale of the problem has reached such proportions that both the NSW Parliament and the Senate have, in recent times, commissioned inquiries into construction insolvency. This paper aims to identify the reasons as to why the construction industry is so susceptible to insolvency, evaluate the effectiveness of any existing insolvency protection measures available to construction firms, and to identify proposed future measures to address the factors causing construction insolvency. The results of a questionnaire survey designed to discover the extent of the construction insolvency problem, as well as building contractors' views with respect to the causes and regulation of construction insolvency, in South Australia are presented. The research found that there is an appetite amongst building contractors for the introduction of further regulation to address construction insolvency. Further, although the research found underbidding to be the biggest contributory factor towards construction insolvency, it appears to be the most difficult factor to address through regulation which explains the paucity of recommendations which directly address underbidding emanating from the Senate inquiry in 2015.
\end{abstract}

Keywords: Construction insolvency, underbidding, security of payment, phoenix companies.

Paper type: Research article

\section{Introduction}

Insolvency represents one of the biggest contemporary issues facing the Australian construction industry. No other single industry sector in Australia is blighted by the scourge of insolvency anywhere near to the same extent as is the construction industry. Data submitted by the Australian Securities and Investment Commission (ASIC) to the Senate Economic References Committee (SERC) (2015) shows that over the period 2009-10 to 2013-14, the construction industry (which produced 8 to $10 \%$ of national gross domestic product) accounted for $23 \%$ of all external administrations in Australia ${ }^{1}$. The same data reported 2,153 corporate insolvency events in the construction industry in the 2013/14 financial year. Notably, these figures do not include insolvent non-corporations (such as small sole traders which account for $60 \%$ of all construction businesses) who have entered into bankruptcy. If bankruptcies of non-corporations were added to corporate insolvencies, no doubt the construction insolvency statistics would be even more alarming.

A large proportion of construction insolvencies are experienced by small contractors and subcontractors; entities with assets of less than $\$ 10,000$ (BIS Shrapnel, 2012). This is perhaps unsurprising as the vast majority of construction firms are small specialist trade contractors. These

\footnotetext{
1 The next largest single identifiable industry is retail trade, accounting for $10 \%$ of all external administrations.
}

Copyright: Construction Economics and Building 2016. (C) 2016 Jeremy Coggins, Bianca Teng and Raufdeen Rameezdeen. This is an Open Access article distributed under the terms of the Creative Commons Attribution 4.0 Unported (CC BY 4.0) License (https://creativecommons.org/licenses/by/4.0/), allowing third parties to copy and redistribute the material in any medium or format and to remix, transform, and build upon the material for any purpose, even commercially, provided the original work is properly cited and states its license.

Citation: Coggins, J., Teng, B. and Rameezdeen, R. 2016. Construction insolvency in Australia: reining in the beast, Construction Economics and Building, 16(3), 38-56. DOI: http://dx.doi.org/10.5130/AJCEB.v16i3.5113

Corresponding author: Jeremy Coggins; Email - Jeremy.Coggins@unisa.edu.au

Publisher: University of Technology Sydney (UTS) ePress 
alarming insolvency statistics, coupled with several recent high profile insolvencies of large building contracting firms leaving hundreds of subcontractors and suppliers unpaid, have in recent times prompted the NSW Parliament (Collins, 2012) and the Senate (SERC , 2015) to conduct urgent inquiries into the construction insolvency problem.

Some may argue that insolvency of firms within a particular industry is not necessarily a bad thing; that natural wastage weeds out the financially weaker, less efficient and commercially reckless from the financially stronger, more entrepreneurial and commercially savvy operators. Whilst this 'survival of the fittest' view may have some foundation per se, in the case of the construction industry it fails to recognise the fact that, due to the hierarchical contracting chains on construction projects, the ill-advised actions of one higher ranking 'officer' in the chain of command can be fatal to countless other 'good soldiers' following behind. ${ }^{2}$ As evidence for this, one need look no further than one of the many high profile head contractor insolvencies in recent years - such as Southern Cross Constructions (NSW) Pty Ltd in New South Wales ${ }^{3}$ and Tagara Builders Pty Ltd in South Australia ${ }^{4}$ to name just two - which have affected hundreds of subcontractors and suppliers and left in their wake tens of millions of dollars owing to creditors. It is this vulnerability of those contractors lower down the contracting chain to the actions of those above which justifies regulation to ensure that principal contractors carry out business in an ethical, responsible and commercially sound manner.

This paper aims to identify the key reasons for the construction insolvency problem in Australia, evaluate the effectiveness of any existing measures available for construction firms to protect themselves against the effects of insolvency and consider what can be done in the way of proposed future measures to address it. The results of a questionnaire survey designed to discover the extent of the construction insolvency problem and building contractors' views with respect to the causes and regulation of construction insolvency in South Australia are presented.

\section{Reasons for the construction insolvency problem}

It is due to a combination of characteristics which are found in the construction marketplace that insolvency has proliferated in the industry. These characteristics include:

- the pyramidal contracting chains on construction projects;

- a predominance of trade credit throughout the construction industry;

- the unsecured creditor status of building contractors and suppliers for work done and/or goods supplied;

- poor payment practices;

- underbidding leading to the prevalence of tight, or even zero, profit margins in the construction industry;

- illegal phoenixing activity;

- undercapitalised firms, which are not financially resilient; and

- poor strategic business management skills of many, particularly smaller, contractors.

\section{Pyramidal contracting chains}

Subcontracting is endemic in the construction industry, with subcontractors providing the vast majority of building work on construction sites, as it facilitates the most cost efficient method for contractors to engage specialised labour. As such, contractors may be categorised according to which tier in the overall contractual structure they are engaged in (see Figure 1). Tier 1 contractors are those contractor firms who are directly engaged under contract by the building developer. Tier 1

\footnotetext{
2 Martial analogies are not uncommon with respect to construction payment - see, for example, Christopher

Rankin and Bob Gaussen's submissions to the Senate Economics References Committee (2015: 14).

3 See further Collins (2012: 8).

${ }^{4}$ See further Small Business Commissioner, South Australia (2016: 5).
} 
contractors are head contractors who establish and run the construction site and manage construction activities to deliver the general contract works. Tier 1 contractors typically procure the labour and materials necessary to physically carry out the construction works by engaging tier 2 contractors under contact. On commercial projects, tier 2 contractors are typically medium to large contractors specialising in the construction of one particular trade (e.g., concreting, masonry, joinery, electrical etc.). Tier 2 contractors supplement their full-time workforce by engaging smaller tier 3 contractors who then, in turn, may supplement their workforce by engaging even smaller tier 4 contractors. Contractors towards the bottom of the contracting chain may very well be small one person sole trader firms.

The existence of pyramidal subcontracting chains on construction projects, as illustrated in Figure 1, means that subcontractors are financially vulnerable to an insolvency or poor payment practice of a contractor higher up in the contracting chain. As stated by the Queensland Building Services Authority (QBSA) (2001), the financial failure of any one party in the contractual chain can cause a domino effect on other parties with those at the bottom most at risk in the event of a client or contractor defaulting. The collapse of one element of the contractual chain or the failure to pass on monies owed can create enormous financial strain on the other parties.

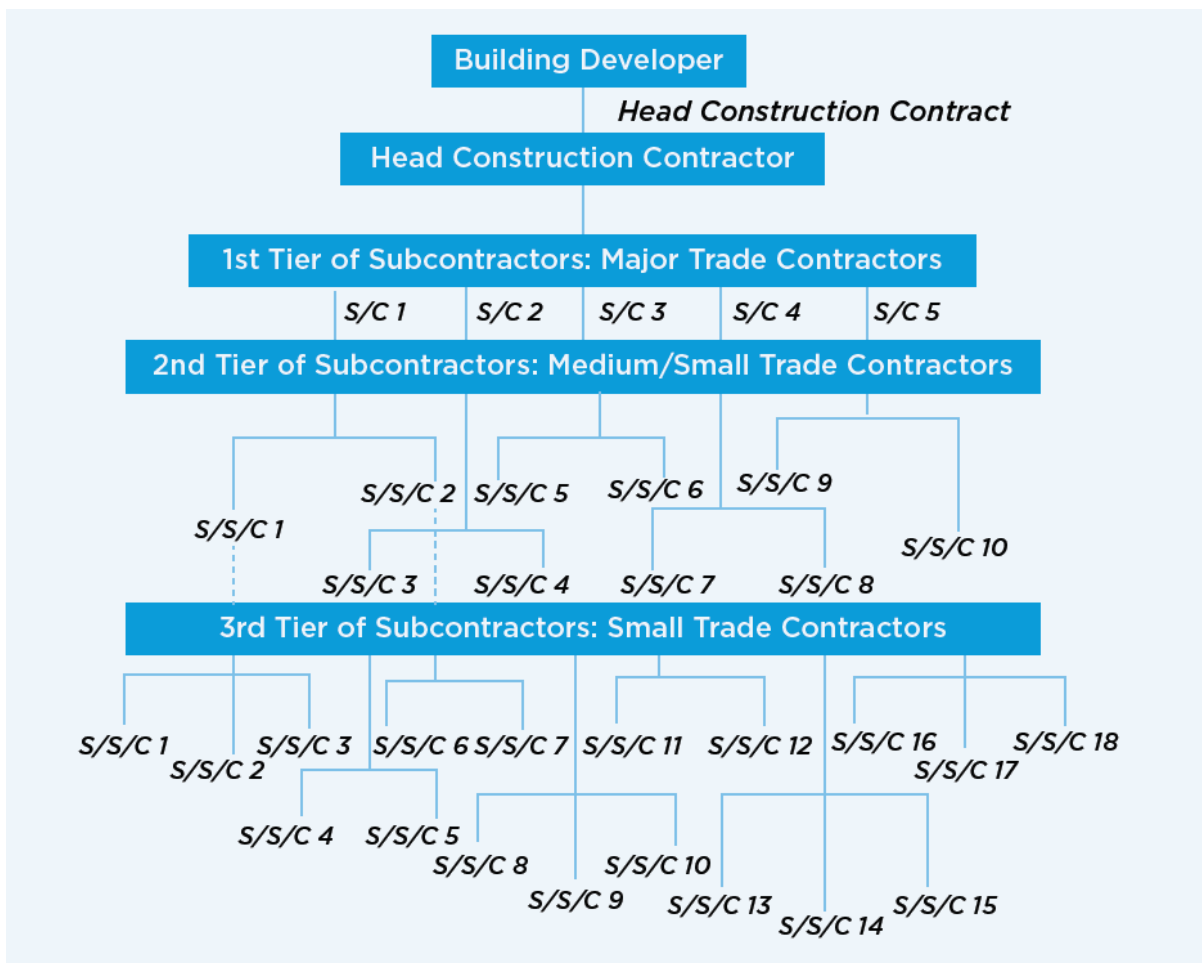

Figure 1: Contractual chains on a construction project (Coggins et al 2016: 36)

\section{Predominance of trade credit}

Construction firms take much more trade credit from their suppliers (two to three times as much, depending on the measure used) as a proportion of their balance sheet than do firms in the rest of the economy (Ive and Murray, 2013). In 2012, in his inquiry into NSW construction insolvency, Collins, (2012) found that the average contractual payment terms between principal contractors and their subcontractors in New South Wales fell somewhere between 45 and 80 days, and in the worst cases extended to between 90 and 120 days $^{5}$.

This commercial pressure to extend trade credit terms to principals is passed on down the contractual chains in the construction industry, as each tier in the chain attempts to obtain ever

\footnotetext{
5 Subsequent to this finding, the NSW Parliament introduced prompt payment provisions into the Building and Construction Industry Security of Payment Act 1999 (NSW) requiring that progress payments under a construction contract become due and payable on the date occurring no later than 15 business days after a payment claim is made by a head contractor, and no later than 30 business days after a payment claim is made by a subcontracto
} 
generous credit terms from firms in the tier below in order to finance their works. This results in the perverse state of affairs whereby the smallest and most vulnerable construction businesses effectively end up financing the construction works on a construction project. Consequently, smaller construction contractors are exposed to extremely poor cash flow and high risk of payment default which accentuates the likelihood of insolvency.

The prevalence of trade credit in the construction industry may be explained by the dominant bargaining position of principal contractors who, as providers of future revenue to their subcontractors, wield considerable influence in commercial transactions with them. Ive and Murray (2013) refer to this as 'dominance hypothesis', and note that under 'dominance hypothesis' subcontractors may lose money by providing credit to their principals at a cheaper rate than they can obtain it.

\section{Unsecured Creditor Status}

An unsecured creditor is a person who is owed money by a business, but does not have a security interest, or charge, over the credit extended (Coggins et al., 2016). Typically, most of the building contractors and suppliers who carry out works and/or supply goods on a construction project are unsecured creditors. In the event of the liquidation of an insolvent business, under corporations law ${ }^{6}$ the proceeds from the realisation of the company's assets must be paid out to creditors in the following order of preference: monies owed to secured creditors, fees and expenses due to the liquidator, any outstanding wages and superannuation contributions owed to the company's employees $^{7}$ and, finally, the debts owed to the company's unsecured creditors.

If the proceeds are not sufficient to repay all the debts owed to unsecured creditors, as is often the case, whatever funds remain are distributed between the unsecured creditors on a pro-rata basis. This means that they may only see a small fraction of the money they are owed (e.g. 30 cents in the dollar) and, furthermore, it may well be up to 12 months before this money is paid.

Indeed, ASIC figures indicate that insolvent businesses in the construction industry had, at the very least, a total shortfall of liabilities over assets accessible by their creditors of $\$ 1.625$ billion in 2013/14 (SERC, 2015). There are some measures which building contractors and suppliers may choose to adopt in order to protect themselves against losses caused by the insolvency of their principal. Contractors and suppliers, for example, may purchase trade credit or insolvency insurance; although many find the cost of such insurance prohibitive and damaging to competitiveness when tendering. There have been several reports and enquiries which have considered the introduction of statutory insolvency insurance to protect subcontractors (see, for example, Collins (2012); Security of Payment Taskforce (WA) (2001).

All these reports, however, have advised against the introduction of such a scheme due to, amongst other reasons:

- insolvency insurance providing no incentive for principal contractors to avoid behaviour that could bring about insolvency, knowing that should their businesses fail, they will not bear personal responsibility for the repayment of their debts; and

- no information being available to suggest that the cost of administering such a potentially expensive scheme would be less than the cost of insolvencies in the sector (Collins, 2012).

In Australia, principals often require their contractors to provide performance bonds as a form of security. This protects a principal against any extra costs in completing the works under the contract by being able to call in the bond amount from the providing surety in the event the contractor becomes insolvent. In the USA, although not in Australia, the use of payment bonds is common whereby a building owner requires their head contractor to provide a payment bond which

\footnotetext{
6 Corporations Act 2001, s 556.

7 Although, according to s 561 of the Corporations Act 2001, claims by employees for unpaid entitlements have priority over secured creditors with floating (but not fixed) charges.
} 
guarantees payment from the surety to any of the head contractors' unpaid subcontractors in the event of head contractor insolvency. This avoids subcontractors obtaining liens over the owner's site $^{8}$.

Contractors and suppliers may also be able to create a security interest over any unpaid goods and materials, which they have supplied to a principal and are not yet installed into the building works, by inserting a retention of title clause into the contract. In such a case, in order to protect this security interest from other secured creditors, a contractor or supplier needs to register their security interest on the Personal Properties Securities Register (PPSR).

\section{Poor payment practices}

Undervalued, withheld and/or non-payment of contractors is both a major cause and effect of construction insolvency. There have been several building and construction industry security of payment reviews in Australia over the past 20 years, for example Price Waterhouse (1996); QBSA (2001); Cole (2003); Stenning and Associates (2006) which have concluded that a significant security of payment problem has existed for decades.

Such poor payment practices have persisted despite the introduction of 'proof of payment' clauses into several standard forms of building contracts in the 1990s, which require a contractor, as a precondition to payment, to provide their principal with evidence that they have paid their subcontractors all monies due and owing. Indeed, the independent inquiry into construction industry insolvency in NSW heard much evidence that false statutory declarations are submitted to the principal by head contractors when, in fact, their subcontractors have not been paid, and that such false declarations were not policed (Collins, 2012).

The Senate Economics References Committee (2015) found that poor payment practices towards subcontractors are caused by the little regard that head contractors often have for the impact of the financial pressures on subcontractors together with the view that, due to their surfeit, subcontractors are expendable and may be easily replaced without financial detriment (due to the holding of retention monies and work received on credit) if they become insolvent.

Additionally, it is not uncommon for contractors, even those who are normally reputable, to find it difficult or impossible to avoid poor payment practices towards their subcontractors when they are inflicted by financial difficulties which may have been caused by their underbidding or the poor payment practices or insolvency of their own principal. Where poor payment practices occur, as illustrated in Figure 2, there is a risk that a vicious cycle of insolvency, non-payment, financial difficulties and poor payment practices may be triggered.

In the worst cases, this vicious cycle may spiral down the hierarchical contractual chain whereby the construction insolvency of a principal contractor plunges unpaid contractors in the tier below into financial difficulties thereby forcing them to engage in poor payment practices with their own subcontractors which leads to construction insolvency.

It is due to this long track record of poor payment practices in the industry that all eight state and territory parliaments across Australia have progressively introduced (between 2000 and 2011) statutory adjudication for payment disputes under somewhat diverse building and construction industry security of payment legislation. Whilst there is general consensus that security of payment legislation has improved payment culture within the industry, there is still much scope for improvement. As Coggins and Bell (2015) note, although adjudication usage rates might at first sight appear quite healthy, there is some evidence to show that adjudication is not as well used as it might have been due to a lack of knowledge about the legislation, as well as a reluctance of contractors to endorse their payment claims as being made under the Act for fear of losing future work. In an attempt to continually improve the effect of the legislation on security of payment,

\footnotetext{
8 Workers and mechanics liens legislation is prevalent in many US states.

9 The PPSR was established under the Personal Properties Securities Act 2009 (Cth).
} 
there have over the past couple of years been significant amendments made, in particular, to the Queensland and NSW Acts which has widened the diversity even further between the legislation interstate $^{10}$.

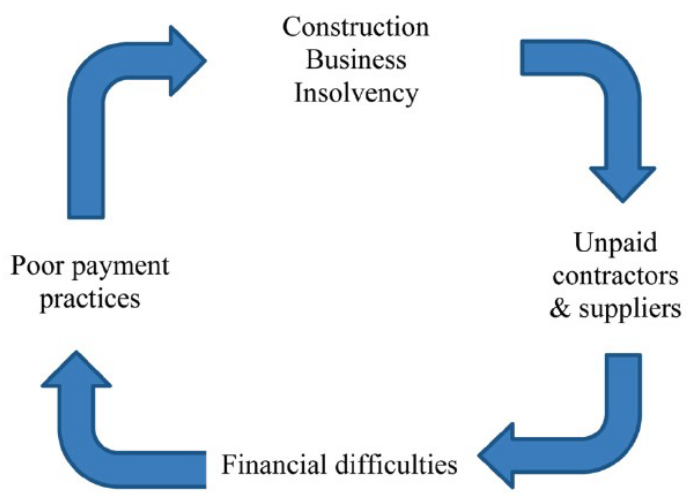

Figure 2: Vicious cycle of insolvency, non-payment, financial difficulties and poor payment practices (Coggins and Lord, 2014, p.225)

In recent years, to further enhance security of payment, there have been calls for the introduction of project trust accounts or project bank accounts (Collins, 2012; SERC, 2015), which require progress payment monies paid by the owner to a head building contractor to be deposited into a trust or project bank account from which all subcontractors are to be paid before the head contractor is permitted to access the monies for their own use. Indeed, project bank accounts have been trialled on selected government projects in $\mathrm{NSW}^{11}$ and $\mathrm{WA}^{12}$ over the past 2 to 3 years, and have recently been recommended for use on South Australian (Small Business Commissioner, South Australia, 2016) and Commonwealth Government projects (SERC, 2015). Additionally, a mandatory requirement for retention monies to be held in trust accounts for projects in excess of $\$ 20$ million was introduced into NSW on 1 May 2015. Such trust or project bank accounts prevent the head contractor from using the subcontractors' progress payment monies and/or associated retention monies for other purposes (e.g., transferring the monies to pay subcontractors on another project), and also protect the subcontractors' progress payment monies from the head contractor's secured creditors (e.g., the bank) in the event of head contractor insolvency.

\section{Underbidding}

The predominant method of tendering used in the construction industry is that of competitive lump sum tendering. This typically encourages high levels of competition in which contractors contractually commit themselves to deliver the specified contract works for a fixed contract sum. Accordingly, Williamson et al. (2004, p.61) observe that "The construction industry consists of a set of markets that form a very competitive system, so competitive that it has been said to be one of the closest systems to perfect competition."

Gerber and Ong (2013) note that price competitiveness is accentuated amongst construction tenderers by owners:

- often viewing price as the most decisive criterion for award contracts, and

- sometimes encouraging too many contractors to tender for a project, particularly in the case of government projects, due to accountability for public funds.

As Gerber and Ong (2013, p.22) state,

"Against this backdrop, contractors are motivated to win a tender by submitting an abnormally low bid notwithstanding any inherent complexities the project may face."

\footnotetext{
10 Furthermore, the ACT Legislative Assembly has recently passed amendments to their legislation, and a consultation process is currently underway for a raft of proposed wide sweeping amendments to the South Australian legislation (Small Business Commissioner, South Australia 2016).

11 See further: https://www.procurepoint.nsw.gov.au/construction-procurement-direction-c2013-02

12 See further: https://www.finance.wa.gov.au/cms/Building_Management_and_Works/New_Buildings/Project_bank_accounts.aspx
} 
In times of economic downturn, competition intensifies even further as a result of "bidding war[s] for the shrinking pool of work which leaves scarcely any profit margin" (Australian Financial Review, 2012, p.44, cited by Collins, 2012, p.8). Indeed, in periods of prolonged economic downturn, it is not uncommon for building contractors to adopt a marginal cost pricing strategy where firms tender to cover the cost of labour, materials and plant (variable costs) to construct the contract works and whatever contribution they can obtain towards covering fixed costs such as head office overheads and returns/profits to the business owners - in an attempt to keep the business running in the short term and ride through the harsh economic climate. Alternatively, firms sometimes may underbid on one project in order to obtain a cash flow to meet payments on another project (Creighton, Handford and Mclure, 1995).

The practice of intentionally bidding at a price lower than cost is sometimes referred to as 'suicide bidding'. A suicide bidding strategy is often associated with a premeditated 'claims mentality', i.e. contractors who deliberately underbid with the intention of clawing back losses and forgone profit by submitting numerous claims during construction. However, this strategy is highly risky, and often results in disputed claims and financial difficulties for the winning contractor, which may kick-start the vicious cycle of insolvency illustrated in Figure 2. Alternatively, 'unwarranted optimism' has been cited as a reason for some contractors' underbidding (Fenwick Elliott, 2015).

The highly competitive nature of the construction market may lead to head contractors engaging in 'bid shopping', which is widely viewed to be an unethical practice. Bid shopping involves head contractors attempting to use the lowest tender price submitted by a subcontractor in a competitive tender process as a 'bargaining chip' in order to drive down tender prices even further by negotiation. As Uher and Davenport (2009, p.211) observe, "Despite the presence of codes of ethics and tendering, bid shopping is actively employed by general contractors."

Bid depositories, which are typically administered by contractors' associations ${ }^{13}$, are used in some US states and Canadian provinces in order to prevent bid shopping. In these jurisdictions, building owners may choose to conduct the tender process for their construction project through a bid depository. Where bid depositories are used, subcontractors submit their tenders on the various trade packages to the bid depository who then passes a copy of the bids to both the building owner and the head contractors who have confirmed their intention to tender for the general project works. The head contractors then compile their own tenders for the general contract works, which must identify which subcontractor's tender was used for each trade, and submit them to the building owner. This prevents bid shopping as the building owner has received the subcontractors' tendered prices from the bid depository, thus bringing transparency to the tendering process. It should be noted, however, that the effectiveness of bid depositories has been somewhat curtailed in the USA by a number of anti-trust legal cases where plaintiff contractors and subcontractors have successfully argued that bid depositories have led to restraint of trade or competition - for example, by only allowing subcontractors who are members of a particular association to submit bids to the bid depository ${ }^{14}$.

\section{Illegal phoenix activity}

Illegal phoenix activity involves the deliberate liquidation of a company, after having transferred the indebted company's assets to a new company, in order to avoid paying creditors, tax or employee entitlements $^{15}$. According to the ATO (2016) website, illegal phoenix activity is typically characterised by the new entity:

- carrying out similar or the same business activities as the former company,

- having directors who are family members or close associates of the director(s) of the former company,

\footnotetext{
13 E.g., the Associated General Contractors of America in Maine, USA.

14 See further Editors, University of Pennsylvania Law Review (1965).
} 
- operating under a similar trading name to the former company, and

- using the same business premises and telephone number (particularly mobile number) as the former company.

In the worst cases, rogue company directors may become serial 'phoenixers', deliberately liquidating company after company in a systematic and cyclical manner ( $\mathrm{PwC}, 2012)$. The Cole Royal Commission into the Building and Construction Industry found that 'there is significant [illegal] phoenix activity in the building and construction industry (SERC, 2015, p.68). Furthermore, SERC (2015) received anecdotal evidence which indicates that phoenixing is considered by some in the industry as merely the way business is done in order to make a profit.

Illegal phoenix activity contributes further to losses which unpaid construction contractors and suppliers suffer due to the insolvency of their principal. The PwC report prepared for the Fair Work Ombudsman on phoenix activity ${ }^{16}$ found that an estimated annual cost of $\$ 1.93$ billion was suffered by businesses as a result of phoenix companies not paying debts or not providing the goods and services that have been paid for by creditors. Although this figure is across all industries, SERC (2015, p.72) commented that "it should be remembered that it is likely that the construction industry accounts for the greatest incidence of illegal phoenixing."

Furthermore, phoenix activity accentuates the damaging phenomenon of underbidding. The Senate Economic References Committee (2015, p.73) received a number of submissions that "phoenix companies are awarded projects through 'net-of-tax-tendering': that is where companies tender quotes calculated on the basis that they will not pay taxes."

\section{Undercapitalised firms}

Undercapitalisation is a commonly cited reason for construction insolvency. In 2013/14, approximately $20 \%$ of external administrators' reports lodged with ASIC nominated undercapitalisation as a cause of business failure (SERC, 2015). Undercapitalisation may be defined as a firm having insufficient funds to carry out their day- to-day business. The Security of Payment Taskforce (WA) (2001, p.8) observes that,

Because the mainstream construction industry is heavily fragmented and specialised with capital equipment usually available for short-term bire it is possible to commence contracting in the industry with very little working capital. So long as there is timely payment for work done, and suitably generous terms of trade and credit available from suppliers, the business can survive on very high gearing or even cash flow alone.

As such, it is typical for construction firms to have little in the way of owner capital; hence, they need to rely on credit and borrowed capital. As Collins (2012) identifies, insufficient capital together with excessive debt is one of the most common causes for construction insolvency. Insufficient working capital and the resultant dependency on timely cash flow means that many construction firms are not financially resilient in the event of payment problems.

\section{Poor business management skills}

The Senate Economic References Committee (2015) found that poor financial and business acumen was a principal cause for insolvencies in the industry, and received submissions from professional associations such as the Master Builders Association and the Housing Industry Association stressing the importance of ensuring that entrants into the industry receive more business skills training before being allowed to practise. The Security of Payment Taskforce (WA) (2001) found that the construction industry is more prone to poor business practices because it is usually technical skill rather than business acumen that induces people to become contractors or subcontractors.

Poor business practice manifests in several ways such as, for example, persistent underbidding through a lack of appreciation of true business costs, a failure to understand both contractual risks

\footnotetext{
15 This definition has been adapted from the ASIC and ATO websites.

16 As cited by the Senate Economic References Committee (2015: 72). 
and terms leading to the inability to recover unexpected losses, and poor cash flow management. Such practices can lead to the rapid demise of a construction business, especially in the harsh and risky financial environment of the construction industry.

\section{The need for empirical research into construction insolvency}

Although much anecdotal evidence exists within government commissioned reports with respect to the causes of construction insolvency (as discussed above), there appears to be little in the way of empirical data obtained via survey of construction industry participants. This paper attempts to take a first step in this direction by presenting the results of a pertinent questionnaire survey targeted at South Australian building contractors. Whilst the survey is limited to the South Australian market, it may be argued the similar nature and characteristics of the construction industry inter-State (particularly in terms of procurement, tendering and regulation) suggests that the results may be representative of building contractors' views nationwide. Having said this, it is recognised that a far more satisfactory approach would be for similar surveys to be carried out in each state and territory, especially given the differing levels of economic activity occurring between them. Accordingly, further research along this line is recommended. The details of the research approach adopted and results obtained for the South Australian survey are presented below.

\section{Research method}

A questionnaire survey was carried out by the authors with the aim of discovering the views of building contractors operating in South Australia (SA) with respect to the extent, causes and regulation of construction insolvency. A questionnaire survey is a systematic method of collecting primary data based on a sample (Tan, 2002). Tan (2002) further highlighted that the purpose of a questionnaire survey is not to consider a specific case in depth but to capture the main characteristics of the population at a given time. Saunders, Lewis and Thornhill (2009) suggested that a questionnaire survey is best suited to a situation where most of the questions are standardized. A questionnaire comprising four distinct sections was developed based on the factors identified in the literature review as follows:

- Section 1 encompasses general demographics of the study sample,

- Section 2 comprises questions to capture respondents' perception of the impacts of insolvency in the South Australian construction industry,

- Section 3 captures the factors that cause insolvency in South Australia, and

- Section 4 captures respondents' awareness regarding mitigation measures that could be used to protect firms from insolvency.

The sampling frame for the study comprised building contractors operating in the South Australian construction market (as the unit of analysis) ranging from relatively small to large and including both head contractors and subcontractors. Therefore, the targeted sample for the survey was general and trade building contractors who had been prequalified for category 3 building work by the SA Department of Planning Transport and Infrastructure. Category 3 building works for general building contractors covers contracts between $\$ 2$ million to $\$ 4$ million and for trade contractors covers contracts between $\$ 500,000$ to $\$ 1$ million. Although prequalified for category 3 works, several contractors in the survey sample were also prequalified for larger contract works at the category 2 level $^{17}$ and, sometimes, also the category 1 level ${ }^{18}$. Using the SA Government's Building Project Information Management System (BPIMS) database, 174 contractors were electronically invited to complete questionnaires. Forty-two questionnaires were completed and returned, giving a response rate of $24 \%$. 


\section{Results}

\section{Data Analysis}

The questionnaire survey responses were analysed using following techniques: (1) frequencies; (2) measures of central tendencies (ranking analysis); (3) relative agreement index, and (4) correlation analysis. The IBM (Version 21) Statistical Packages for Social Sciences (SPSS) software was used for the analysis.

Frequencies: Section 1 of the survey instrument was mostly composed of profile of the sample structured around nominal variables. According to Forza (2002), the relevant type of analysis for such data is "frequencies analysis" and it enables the reference to the number of times various subcategories of certain phenomenon occur.

Measures of Central Tendencies: Some of the questions in Sections 2 and 4 use a Likert scale to obtain respondents' opinions on impacts of insolvency and effectiveness of mitigation measures as discussed in the research methods section. The underlying objective of this analysis was to ascertain the relative magnitude of the issue and the effectiveness of purported solutions through the examination of the reported descriptive statistics (mean scores, standard deviation and coefficient of variation). As with previous studies (Kumaraswamy and Chan, 1998; Yuan, Shen and Wang, 2011; Doloi et al., 2012) rank differentiation where two or more variable had the same mean values was achieved through examination and selection of the variable with the lowest standard deviation or coefficient of variation (CV). Based on the classification used to discuss the degree of central tendency, a benchmark of 3.40 was used to identify the significance of the responses. It should however, be noted that different approaches exist in literature for ascertaining the cut-off points when a 5-Point Likert scale is used to measure the levels of agreement. For example, Yuan, Shen and Wang (2011) adopted the cut-off mean value of 3.00.

Relative Agreement Index (RAI): In addition to measures of central tendency, RAI was used to rank the perceived effectiveness of different mitigation measures put forward to respondents under section 5 of the questionnaire survey. According to past researchers, RAI provides an unbiased tool to rank these measures according to the following equation (Holt, 2014).

Where:

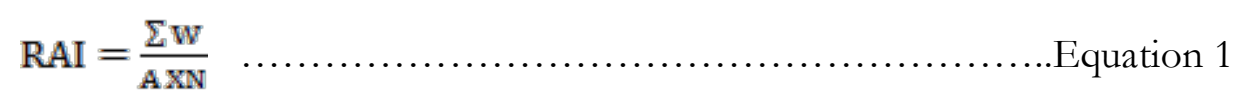

$\mathrm{W}=$ weighting as assigned by each respondent in a range 1 to 5 of the Likert scale;

$\mathrm{A}=$ the highest weight (5);

$\mathrm{N}=$ the total number in the sample.

\section{Profile of study sample}

The positions of the individuals who responded on behalf of their firms are shown in Table 1. It shows that majority (59.5\%) of the respondents where at executive level, either as the Chief Executive Officer, General Manager or Director of their respective firms, followed by senior managers representing operations $(16.7 \%)$, commercial management $(11.9 \%)$ and contracts management $(11.9 \%)$. It is very clear that the majority of respondents occupy very high management positions in the company and are capable of assessing the companies' financial performance and future prospects.

\footnotetext{
$17 \$ 4$ million to $\$ 10$ million for general contractors, and $\$ 1$ million to $\$ 2.5$ million for trade contractors.
}

$18 \$ 10$ million to $\$ 50$ million for general contractors, and over $\$ 2.5$ million for trade contractors. 
Table1: Job positions of respondents

\begin{tabular}{|c|c|c|c|}
\hline Position & $\begin{array}{l}\text { Number of } \\
\text { respondents }\end{array}$ & $\%$ & Cumulative \\
\hline $\begin{array}{l}\text { Owner, Chief Executive Officer, Chief Operating } \\
\text { Officer, General Manager, Director, Managing Director }\end{array}$ & 25 & 59.5 & 59.5 \\
\hline $\begin{array}{l}\text { Associate Director, Office/Branch Manager, } \\
\text { Operations Manager, Project Manager }\end{array}$ & 7 & 16.7 & 76.2 \\
\hline Commercial Manager, Estimating Manager, Estimator & 5 & 11.9 & 88.1 \\
\hline Contracts Manager, Contract Administrator & 5 & 11.9 & 100 \\
\hline
\end{tabular}

Table 2: Organisational profile of study sample

\begin{tabular}{|c|c|c|c|}
\hline Characteristics & $\begin{array}{l}\text { Number of } \\
\text { respondents }\end{array}$ & $\%$ & Cumulative \\
\hline \multicolumn{4}{|l|}{ Main role (sector) } \\
\hline General building & 16 & 38.1 & 38.1 \\
\hline Trade & 26 & 61.9 & 100.0 \\
\hline \multicolumn{4}{|c|}{ Principal type of construction work } \\
\hline Commercial & 38 & 90.5 & 90.5 \\
\hline Public Works & 4 & 9.5 & 100.0 \\
\hline \multicolumn{4}{|c|}{ Length of activity in the construction industry (years) } \\
\hline$<5$ & 2 & 4.8 & 4.8 \\
\hline $6-10$ & 3 & 7.1 & 11.9 \\
\hline $11-15$ & 4 & 9.5 & 21.4 \\
\hline $16-25$ & 12 & 28.6 & 50.0 \\
\hline$>25$ & 21 & 50.0 & 100.0 \\
\hline \multicolumn{4}{|c|}{ Number of employees ${ }^{2}$} \\
\hline $1-2$ & 1 & 2.4 & 2.4 \\
\hline $3-10$ & 5 & 11.9 & 14.3 \\
\hline $11-20$ & 10 & 23.8 & 38.1 \\
\hline$>20$ & 26 & 61.9 & 100.0 \\
\hline
\end{tabular}

The profile of the study sample is reported in Table 2. Of the forty-two respondent firms,

- $62 \%$ operate as trade contractors and $38 \%$ as general building contractors;

- $90 \%$ of the respondent firms primarily participate in the commercial construction sector and $10 \%$ in the public construction sector;

- $50 \%$ of the firms have been operating in South Australia for more than 25 years, $29 \%$ between 15 to 25 years, $10 \%$ between 10 to 15 years, 7\% between 5 to 10 years, and 5\% for less than 5 years; and

- $62 \%$ of the firms employ more than 20 full-time employees, $24 \%$ between eleven to twenty full-time employees, $12 \%$ between three to ten full-time employees, and $2 \%$ between one to two full-time employees.

\section{Vulnerability to insolvency}

Respondents were asked to indicate on a scale of 1 to 5 how vulnerable they believe the South Australian construction industry is to business insolvency. With a mean score of 4.07 and a standard deviation of 0.80 , respondents have sent a clear message that the prospect of insolvency is high for construction businesses in South Australia as shown in Table 3. More than two thirds 
of the respondents $(76 \%)$ gave a ranking of either 4 or 5 , indicating that the vast majority believed the construction industry is highly vulnerable to insolvency.

Respondents were also ask to indicate on a scale of 1 to 5 how much of a threat they believe the insolvency of other construction firms was to the financial wellbeing of their own organisation. A mean score of 3.43 indicates that respondents are not ruling out the impacts on the financial wellbeing of their own company due to the insolvency of other firms. Almost half of the respondents gave a ranking of either 4 or 5 , indicating that they believe the financial wellbeing of their firm was under considerable threat from the insolvency of other construction firms. However, the robustness of this finding is somewhat undermined by the relatively low mean and relatively high standard deviation values of the responses as compared to those with respect to industry vulnerability to business insolvency.

Table 3: Respondents' perception on vulnerability to insolvency and threat on financial wellbeing

\begin{tabular}{|c|c|c|c|c|c|}
\hline & Min & $\operatorname{Max}$ & $\mathbf{M S}^{1}$ & $\mathrm{SD}^{2}$ & $\mathrm{CV}^{3}$ \\
\hline $\begin{array}{l}\text { How vulnerable SA construction industry to business } \\
\text { insolvency }\end{array}$ & 2.00 & 5.00 & 4.07 & 0.80 & 19.66 \\
\hline $\begin{array}{l}\text { How much of a threat other companies' insolvency } \\
\text { could pose on the respondents' company }\end{array}$ & 1.00 & 5.00 & 3.43 & 1.07 & 31.20 \\
\hline
\end{tabular}

The above perceptions were verified by asking the respondents how many times in the last 3 years their firm has lost money owing to insolvency of other firms. As shown in Table 4, 74\% of the respondents' firms have lost money at least once during last three years. This confirms a serious situation where vulnerability of, and threat to, firms due to insolvency is very high pointing to the need for urgent mitigation measures to be put in place to deal with the issue.

Table 4: Magnitude of threat due to insolvency of other firms

\begin{tabular}{|lccc|}
\hline $\begin{array}{l}\text { Number of times the company has lost money } \\
\text { owing to insolvency of other firms }\end{array}$ & $\begin{array}{c}\text { Number of } \\
\text { respondents }^{1}\end{array}$ & $\mathbf{\%}$ & Cumulative \\
\hline$>4$ & 2 & 4.8 & 4.8 \\
\hline 3 & 8 & 19.0 & 23.8 \\
\hline 2 & 15 & 35.7 & 59.5 \\
\hline 1 & 6 & 14.3 & 73.8 \\
\hline Never & 11 & 26.2 & 100.0 \\
\hline Note: ${ }^{1}$ Total number of respondents based on 42 completed responses. & & \\
\hline
\end{tabular}

In order to establish the interactions among these three variables, the 'Pearson correlation coefficient' and 'Coefficient of determination' was computed and the results summarised in Table 5. It provided an opportunity to test the possibility of respondents' past experience to determine the perceptions on vulnerability and threat. Similarly, it verified whether the perceived vulnerability and threat have a common founding.

The significant correlations were between losses and vulnerability $(r=0.403 ; n=42 ; p=0.008)$ and vulnerability and threat $(\mathrm{r}=0.493 ; \mathrm{n}=42 ; \mathrm{p}=0.001)$ suggesting that respondents perception on vulnerability to insolvency is influenced by past losses to the company and potential threats posed by insolvency of other companies. This finding relates to the very high mean score given by respondents to the potential vulnerability of construction firms in South Australia with very low coefficient of variation (MS= 4.07; $C V=19.66)$. This indicates that perceived vulnerability is a collective voice and founded through past experience rather than a spontaneous response. 
Table 5: Results of Pearson's correlation coefficients ( $\mathrm{r}$ ) and coefficient of determination $\left(\mathrm{r}^{2}\right)$ among vulnerability, threat and losses

\begin{tabular}{|lccc|} 
& \multicolumn{3}{c|}{ Coefficient of determination $\left(\mathbf{r}^{2}\right)$} \\
\hline Variable: & Losses & Vulnerability & Threat \\
\hline Losses & 1.000 & 16.24 & 4.84 \\
\hline Vulnerability & $0.403^{* *}$ & 1.000 & 24.30 \\
\hline Threat & 0.220 & $0.403^{* *}$ & 1.000 \\
\hline Note: ${ }^{* *}$ Correlation is significant at $(\mathrm{p}<0.01)$ level (2-tailed) & \\
\hline
\end{tabular}

\section{Factors influencing insolvency}

Respondents' views were sought on five factors that are responsible for insolvency at the firm level according to the literature discussed earlier. The factors beyond the firm level were not within the scope of this study and not included in the questionnaire survey. Respondents were initially asked to simply indicate whether the believed each of the factors per se contributed to the insolvency problem. As shown in Table 6, most respondents identified poor payment practices as a cause of insolvency followed by underbidding, poor financial management skills, procurement methods and undercapitalised firms. Respondents were also asked to rank these five factors comparatively in ascending order $(1=$ most contributory factor, $2=$ next most contributory factor, etc.) according to level of contribution to the construction insolvency problem. As shown in Figure 3, forty-eight percent of the respondents ranked underbidding as the most contributory cause followed by poor financial management skills $(24 \%)$, undercapitalised firms (14\%), procurement methods $(12 \%)$, and poor payment practices $(7 \%)$.

Table 6: Respondents' agreement on factors influencing insolvency

\begin{tabular}{|lcc|} 
& Frequency & Rank \\
\hline Poor payment practices & 40 & 1 \\
\hline Underbidding & 39 & 2 \\
\hline Poor financial management skills & 37 & 3 \\
\hline Procurement methods & 34 & 4 \\
\hline Undercapitalized firms & 28 & 5 \\
\hline Note: Based on total number of 42 responses & & \\
\hline
\end{tabular}

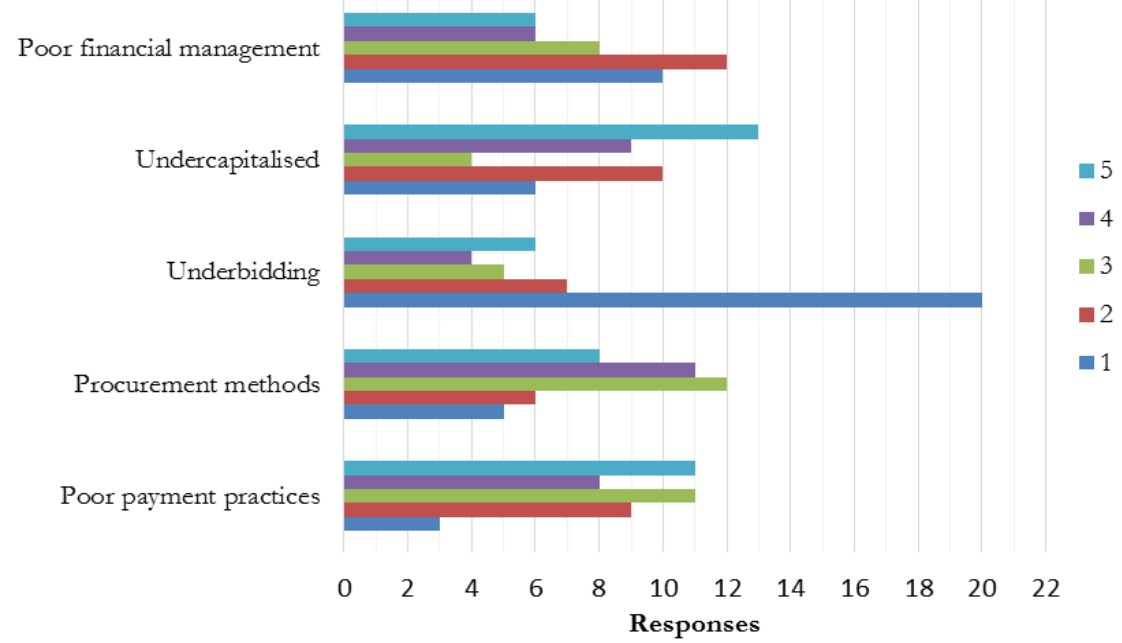

Figure 3: Contribution to construction insolvency ranking $((1=$ most contributory factor, $2=$ next most contributory factor, etc.) 


\section{Mitigation measures}

Respondents were asked to indicate their firm's awareness and use with respect to various measures that are currently available in the construction industry to protect firms from the effects of insolvency. As shown in Table 7, awareness of all these measures was high with the exception of the personal properties securities register of which about $50 \%$ of respondents were aware.

Table 7: Firms' awareness of mitigation measures that are currently available

\begin{tabular}{|lcc|}
\hline Building and Construction Industry Security of Payment Act & Frequency & Rank \\
\hline Prequalification of tenders & 42 & 1 \\
\hline $\begin{array}{l}\text { Contractual clauses requiring Contractor to provide proof of payment to } \\
\text { their subcontractors }\end{array}$ & 41 & 2 \\
\hline Retention & 40 & $3=$ \\
\hline Performance bond/bank guarantee & 40 & $3=$ \\
\hline $\begin{array}{l}\text { Contractual clauses allowing Principal to take work out of hands of an } \\
\text { insolvent contractor }\end{array}$ & 35 & 6 \\
\hline Personal Property Securities Register & 26 & 7 \\
\hline Note: Based on total number of 42 responses & & \\
\hline
\end{tabular}

As shown in Table 8, respondents indicated that the use of these measures in their firms varied with retention being the most popular followed by performance bonds, prequalification of tenders and so on. Interestingly, the uptake of the building and construction industry security of payment legislation and contractual 'take out' clauses were relatively low. The use of the personal properties securities register was very low indicating this measure is not well used among construction firms operating in South Australia. Surprisingly, although respondents were well aware of the construction industry security of payment legislation, its usage was not as high as expected.

Table 8: Firms' usage of mitigation measures that are currently available

\begin{tabular}{|lcc|}
\hline Retention & Frequency & Rank \\
\hline Performance bond/bank guarantee & 34 & $1=$ \\
\hline Prequalification of tenders & 34 & $1=$ \\
\hline $\begin{array}{l}\text { Contractual clauses requiring Contractor to provide proof of payment to } \\
\text { their subcontractors }\end{array}$ & 31 & 3 \\
\hline Building and Construction Industry Security of Payment Act & 16 & 4 \\
\hline $\begin{array}{l}\text { Contractual clauses allowing Principal to take work out of hands of an } \\
\text { insolvent contractor }\end{array}$ & 14 & 6 \\
\hline Personal Property Securities Register & 3 & 7 \\
\hline Note: Based on total number of 42 responses & & \\
\hline
\end{tabular}

Respondents were also asked to indicate on a scale of 1 to 5 how effective they believe these measures to be with respect to preventing construction insolvency and lessening of financial impacts to the firm. As shown in Table 9, three measures were included under prevention of insolvency and four under lessening of financial impacts. With the highest mean score, respondents have indicated that Building and Construction Industry Security of Payment Act is the most effective out of the three measures in preventing insolvency. However, with a mean score of 2.73 that measure is not considered to be statistically significant in preventing insolvency (MS=3.40). Except for performance bonds $(M S=3.36)$, the other three measures were not considered significant by respondents in lessening financial impacts due to insolvency. Personal property securities register was considered to be the least effective out of the four factors. A high disparity could be observed among respondents with regard to effectiveness of measures such as personal property securities, prequalification of tenders and proof of payment (CV>50\%). 
Table 9: Respondents' perception on effectiveness of mitigation measures on preventing insolvency and lessening of impact of insolvency

\begin{tabular}{|c|c|c|c|c|c|c|}
\hline & Min & $\operatorname{Max}$ & MS $^{1}$ & $\mathrm{SD}^{2}$ & $\mathrm{CV}^{3}$ & RAI \\
\hline \multicolumn{7}{|l|}{ Prevention of insolvency } \\
\hline $\begin{array}{l}\text { Building and Construction Industry Security of } \\
\text { Payment Act }\end{array}$ & 1.00 & 5.00 & 2.73 & 1.19 & 43.59 & 0.58 \\
\hline Prequalification of tenders & 1.00 & 5.00 & 2.44 & 1.25 & 51.23 & 0.49 \\
\hline $\begin{array}{l}\text { Contractual clauses requiring Contractor to provide } \\
\text { proof of payment to their subcontractors }\end{array}$ & 1.00 & 5.00 & 2.20 & 1.10 & 50.00 & 0.44 \\
\hline \multicolumn{7}{|l|}{ Lessening of financial impact } \\
\hline Performance bond/bank guarantee & 1.00 & 5.00 & 3.36 & 1.19 & 35.42 & 0.67 \\
\hline Retention & 1.00 & 5.00 & 2.69 & 1.16 & 43.12 & 0.54 \\
\hline $\begin{array}{l}\text { Contractual clauses allowing Principal to take work } \\
\text { out of hands of an insolvent contractor }\end{array}$ & 1.00 & 5.00 & 2.69 & 1.28 & 47.58 & 0.54 \\
\hline Personal Property Securities Register & 1.00 & 5.00 & 2.02 & 1.12 & 55.45 & 0.40 \\
\hline
\end{tabular}

\section{Government intervention}

Respondents were asked to comment on the need for government intervention to protect construction firms from insolvency and help the construction industry to improve its efficiency. The descriptive statistics of the responses are shown in Table 10. Firstly, the respondents were asked to indicate on a scale of 1 to 5 how urgent they believe is the need for government regulation is in order to reduce construction insolvency in South Australia. With a mean score of 3.83, they agreed that there is urgency for the government to act. More than half $(59 \%)$ of the respondents believe that government regulation is either urgently or very urgently needed. A relatively low CV $(26.63 \%)$ indicates a high agreement among respondents for urgent government intervention. Secondly, the respondents were asked to indicate either in the affirmative or negative as to which specific mischiefs (or areas) government intervention is needed in order to address the insolvency problem. They indicated that government intervention is most needed in order to address underbidding followed by poor payment practices, poor financial management and undercapitalization as shown in Table 11.

Table 10: Respondents' perception on need for government intervention

\begin{tabular}{|c|c|c|c|c|c|}
\hline & Min & $\operatorname{Max}$ & MS1 & $\mathrm{SD}^{2}$ & $\mathrm{CV}^{3}$ \\
\hline $\begin{array}{l}\text { How urgently government regulations should be } \\
\text { introduced to reduce construction insolvency in South } \\
\text { Australia }\end{array}$ & 1.00 & 5.00 & 3.83 & 1.02 & 26.63 \\
\hline
\end{tabular}

Table 11: Areas where government intervention is mostly needed

\begin{tabular}{|lcc|}
\hline & Frequency & Rank \\
\hline Underbidding & 35 & 1 \\
\hline Poor payment practices & 34 & 2 \\
\hline Poor financial management skills & 31 & 3 \\
\hline Undercapitalized firms & 28 & 4 \\
\hline Note: Based on total number of 42 responses & & \\
\hline
\end{tabular}




\section{Discussion of results}

In accordance with the high incidence of construction insolvencies reported in recent times, the survey found that building contractor firms in South Australia firmly viewed that the construction industry is vulnerable to insolvency. The survey also found, although to a lesser statistically significant extent, that building contractor firms in South Australia view the insolvency of other construction firms as a threat to their own firm. It is perhaps surprising that this particular finding was not more robust given both that the industry operates on the basis of hierarchical contracting chains and that the survey also found that a majority of the respondent firms had lost money at least twice over the past three years due to the insolvency of other firms.

The three factors most identified by the respondents as being a cause of the construction insolvency problem were poor payment practices, underbidding, and poor financial management skills. However, in terms of comparative level of contribution to the construction insolvency problem, the respondents found the top three most contributory causes to be underbidding followed by poor financial management skills and undercapitalised firms. Somewhat surprisingly, perhaps, although the vast majority of respondents identified that poor payment practices was a factor causing construction insolvency, they found it to be the factor which least contributes to the construction insolvency problem. One possible explanation for this could be the focus of Australian parliaments in recent years on passing extensive building and construction industry payment legislation which has improved to some degree the payment culture generally within the industry. Although, having said this, the survey also found that security of payment legislation (along with prequalification of tenders and contractual 'proof of payment' clauses) was not statistically significant as a measure per se for preventing construction insolvency. This latter finding accords with the fact that a high construction insolvency rate still exists in NSW despite security of payment legislation having been in operation there since the year 2000 .

The survey found that awareness of respondents was high with respect to certain existing measures - namely security of payment legislation, prequalification of tenders, contractual 'proof of payment' clauses, performance bonds/bank guarantees and contractual 'take out' clauses - for firms in the construction industry to protect themselves against both insolvency and financial impact of insolvency. However, respondents' awareness of the personal property securities register as a means of protecting their security interests in the event of insolvency was significantly lower.

Of these measures, regular use of retention monies, performance bonds, prequalification of tendering contractors and contractual 'proof of payment' clauses was high. In comparison, use of the building and construction industry security of payment legislation and contractual 'take out' clauses was relatively low, with use of the personal properties securities register being very low. The relatively lower usage of security of payment legislation may possibly be explained by the potential for use of the legislation to negatively impact upon the future working relationship between contractor and principal. The low usage of the personal properties securities register may be explained by the lack of awareness of the register found to exist amongst many of the respondents. The use of retention, contractual 'take out' clauses and the personal properties securities register were not found to be statistically significant in the opinions of the respondents as measures per se for lessening the financial impact of others' insolvency upon their own firm. Only the use of performance bonds or bank guarantees was found to have any significance in this respect.

The survey found, to some degree of statistical significance, that the respondents believe urgent government intervention is needed in order to tackle the construction insolvency problem. More specifically, the survey also found that over $80 \%$ of the respondents desire further regulation to address underbidding and poor payment practices, with $74 \%$ desiring further regulation to address poor financial management skills, and $67 \%$ desiring further regulation to address undercapitalisation of firms. 


\section{Conclusion}

The Australian construction industry is characterised by an extremely high rate of business insolvency due to a unique combination of characteristics present in the construction marketplace including contracting chains, trade credit, poor payment practices, underbidding, undercapitalisation of firms and poor business skills. The construction insolvency problem is accentuated by the phenomenon of phoenix companies, where new companies arise out of the ashes of old companies that have been deliberately traded into insolvency. Phoenixing further fuels poor payment practices and underbidding with the construction industry.

In addressing the construction insolvency problem, Australian parliaments have to date directed most of their regulatory focus towards tackling of poor payment practices via the enactment and subsequent amendment of the various building and construction industry security of payment legislation which exists nationwide. Although this has been a huge step in the right direction in encouraging a fairer payment culture, the legislation by itself has proven to be insufficient to alleviate in any significant way the construction insolvency problem. As evidence for this, one need look no further than the NSW experience where 1,113 construction insolvencies occurred in the 2011/12 financial year (Collins, 2012) despite security of payment legislation having been operational there for over a decade. As such, a multi-faceted regulatory approach is needed to address the construction insolvency problem, of which security of payment legislation is but one, albeit important, component.

The questionnaire survey data presented in this paper indicates that there is an appetite amongst building contractors to address the construction insolvency problem - particularly in the key areas of poor payment practices, poor financial management skills, undercapitalisation of firms and underbidding. With respect to the first three of these areas, the recent SERC (2012) report into insolvency in the Australian construction industry has made recommendations to tighten regulations via, amongst other things: unification of the building and construction industry security of payment legislation (by the enactment of a Commonwealth act), the trialing and evaluation of project bank accounts on Commonwealth projects, closer scrutiny and prosecution of false 'proof or payment' statutory declarations, random financial health spot -checks on construction firms by building license regulators, requiring building license holders to demonstrate they hold adequate financial backing for the scale of intended project, and requiring building license holders to provide evidence they have completed an agreed level of financial and business training program (SERC, 2015). Additionally the Committee made several recommendations with respect to introducing regulatory measures in order to curb illegal phoenixing activity.

Notably, however, the Senate Economics References Committee (2015) did not make any recommendations which directly addressed the issue of underbidding in the construction industry19. The practice of underbidding was found by the survey data presented in this paper to be the biggest contributor to construction insolvency. The paucity of recommendations to directly address underbidding is understandable given that the regulation of pricing would likely be viewed as an unreasonable incursion into the territory of free market economics and anticompetitive in nature. It is suggested that preliminary proposals for further consideration, with respect to measures which could potentially restrict underbidding practice, may include: the introduction of bid depositories on government projects to eradicate bid shopping; prohibiting 'bad faith' underbidding as a requirement of the national Building Code or state building codes (where they exist), thereby banning offenders from tendering on government-funded projects; and looking into the legal feasibility of the Australian Competition and Consumer Commission bringing actions for misleading and deceptive conduct, under Section 18 of the Australian Consumer Law, against bad faith under bidders.

\footnotetext{
${ }^{19}$ Although, the Committee (2015: 165) did consider the Law Reform Commission of Western Australia's (1995: 54) explanation that the use of trust accounts on construction projects would render it not to be in a head contractor's interest to underbid for a project.
} 
Having said this, it is recognised that it will be difficult to detect where the fine line has been crossed between a contractor pricing a tender over competitively (perhaps due to poor financial estimating or unwarranted optimism) in good faith (i.e. 'unwarranted optimism'), and a contractor deliberately pricing a tender below cost in bad faith with the intention of subsequently attempting to reclaim losses via contractual claims, poor payment practices to subcontractors and/or phoenixing their company to escape tax and other liabilities. Nevertheless, given the scale of construction insolvency in Australia and the direct impact which underbidding has upon the problem, further investigation into how underbidding can be discouraged may be too important an issue to ignore.

\section{References}

ASIC, 2016. Small business - illegal phoenix activity. [online] Available at: http://asic.gov.au/for-business/yourbusiness/small-business/compliance-for-small- business/small-business-illegal-phoenix-activity/ [Accessed 26 July 2016].

ATO, 2016. Fraudulent phoenix activities. [online] Available at: https://www.ato.gov.au/General/The-fight-againsttax-crime/Our-focus/Fraudulent-phoenix-activities/ [Accessed 26 July 2016].

Australian Bureau of Statistics (ABS), 2012. 2011-12 Private Sector Construction Industry Australia, 8772.0, Canberra: Australian Bureau of Statistics.

Australian Financial Review, 2012. Building industry slump claims another victim, Australian Financial Review, 15 November .

BIS Shrapnel, 2012. NSW Construction Activity and Insolvencies Report - NSW Inquiry into Construction Insolvency, November 2012. Sydney: BIS Shrapnel.

Coggins, J. and Bell, M., 2015. Australia's security of payment experience: A crystal ball for

Malaysia and Hong Kong', International Construction Law Review, 32(4), pp.420-54.

Coggins, J., Davie, T., Earls, T. and Evans, P., 2016. Understanding Construction Law. Australia: LexisNexis Butterworths.

Coggins, J. and Lord, W., 2014. Towards the reduction of construction insolvency: Examining the 'supporting statement' requirement in New South Wales. Building and Construction Law Journal, 30(4), pp.224-37.

Cole, T., 2003. Final Report of the Royal Commission into the Building and Construction Industry, Canberra: Commonwealth of Australia.

Collins, B., 2012. Final Report of the Independent Inquiry into Construction Industry Insolvency in NSW Sydney: NSW Government.

Creighton, P., Handford, P. and Mclure, C.J. 1995. Discussion Paper on Financial Protection in the Building and Construction Industry. Project No 82. Perth, WA: Law Reform Commission of Western Australia.

Doloi, H., Sawhney, A., Iyer, K.C. and Renata, S., 2012. Analysing factors affecting delays in Indian construction projects. International Journal of Project Management, 30, pp.479-89. doi: http://dx.doi.org/10.1016/j.ipproman.2011.10.004

Fenwick Elliott, R., 2015. Construction Insolvency. Address to University of South Australia's Builders' Organisation of Students and Staff Annual Dinner, National Wine Centre, Adelaide, 6 November.

Forza, C., 2002. Survey research in operations management: a process-based perspective. International journal of operations \& production management, 22(2), pp.152-94. doi: http://dx.doi.org/10.1108/01443570210414310

Gerber, P., and Ong, B., 2013, Best practice in construction disputes: avoidance, management and resolution, LexisNexis Butterworths, North Ryde, NSW.

Holt, G.D., 2014. Asking questions, analyzing answers: relative importance revisited. Construction Innovation, 14(1), pp.2-16 doi: .http://dx.doi.org/10.1108/CI-06-2012-0035

Ive, G., and Murray, A., 2013, Trade Credit in the UK Construction Industry: An Empirical Analysis of Construction Contractor Financial Positioning and Performance, BIS Research Paper Number 118, Department for Business Innovation \& Skills, UK.

Kumaraswamy, M.M. and Chan, D.W.M., 1998. Contributors to construction delays. Construction Management and Economics, 16(1), pp.17-29. doi: http://dx.doi.org/10.1080/014461998372556

Price Waterhouse, 1996. Improving Security of Payment in the Building and Construction Industry. Melbourne: National Public Works Council Inc.

Queensland Building Services Authority (QBSA), 2001. Discussion Paper on Security of Payment. Brisbane: Queensland Building Services Authority.

Saunders, P., Lewis, P. and Thornhill, A., 2009. Research methods for business students, 5th ed. Edinburgh Gate, England: Pearson Education Limited. 
Security of Payment Taskforce (WA), 2001, Security of Payment Taskforce for the Western Australian building and construction industry : report to the Minister for Housing and Works, Deptartment of Housing and Works, Perth, Western Australia.

Senate Economic References Committee, 2015. T just want to be paid', Insolvency in the Australian Construction Industry. Canberra: Commonwealth of Australia.

Small Business Commissioner South Australia, 2016. Consultation Paper on Proposed Changes to the Building and Construction Industry Security of Payment Act 2009 and other initiatives to improve payment to subcontractors in the building and construction industry. June 2016. Adelaide: Government of South Australia.

Stenning and Associates Pty Ltd., 2006. Final Report on Security of Payment in the Tasmanian Building and Construction Industry prepared for the Minister Administering the Building Act 2000. Hobart, Tasmania.

Tan, W., 2002. Practical research methods. Singapore: Prentice Hall.

Uher, T.E. and Davenport, P., 2009. Fundamentals of Building Contract Management, 2nd ed. Sydney: UNSW Press.

Williamson, M., Wilson O., Skitmore, M., and Runeson, G., 2004, "Client Abuses of the Competitive Tendering System: Some General Principles and a Case Study", Journal of Construction Research, 5(1), pp. 61-74. doi: http://dx.doi.org/10.1142/S160994510400005X

Yuan, H., Shen, L. and Wang, J., 2011. Major obstacles to improving the performance of waste management in China's construction industry. Facilities, 29(5/6), pp.224-42. doi: http://dx.doi.org/10.1108/02632771111120538 